
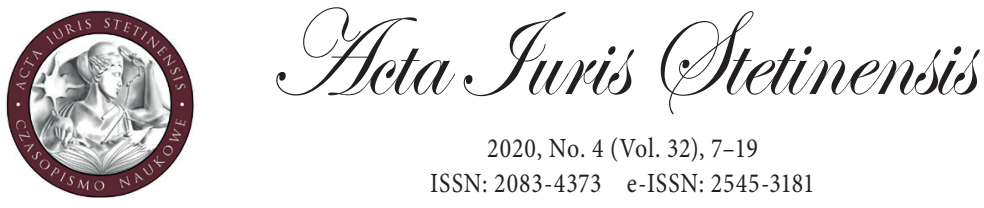

2020, No. 4 (Vol. 32), 7-19

ISSN: 2083-4373 e-ISSN: 2545-3181

DOI: 10.18276/ais.2020.32-01

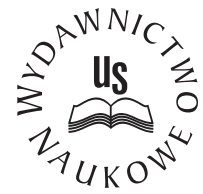

Javier Martínez Calvo

Ph.D.

Zaragoza University, Spain

e-mail: javiermc@unizar.es

ORCID ID: 0000-0001-9658-6744

\title{
Shared custody configuration in Spanish law
}

\begin{abstract}
The paper deals with the specific organization of the shared custody regime in Spanish law. This requires a separate analysis of two aspects: what the physical organization will be like and how the time will be distributed among the parents. With regard to the first question, there are two possible alternatives for the physical organization of the shared custody regime: that the children remain in the same home and the parents rotate, or that the children rotate between their parents' homes. Both possibilities are analyzed, considering the advantages and disadvantages of each, as well as their practical repercussions, through the study of the judgements of our courts. With regard to the second aspect to be analyzed - the distribution of time between parents, as we know, shared custody does not necessarily imply an equal distribution of time, although it does seem to be similar, as this is the main data that allows it to be differentiated from an exclusive custody regime that involves a wide regime of visits for the non-custodial parent. The paper attempts to determine the necessary time requirement to be able to speak of shared custody and addresses the issue of the specific duration of periods of alternation - which may be long and extended in time or, on the contrary, short and frequent. For this, once again, the jurisprudence emanating from our courts is taken into account, as well as the views of the authors who have worked on this issue.
\end{abstract}

Keywords: family law, civil law, Spanish law, shared custody configuration. 


\section{Introduction}

In order to address the specific configuration of the shared custody regime, it is necessary to analyze two aspects separately: on the one hand, what the physical organization of the regime will be like and, on the other, what the allocation of time between the parents will be like.

Neither of the two questions has been foreseen either by the Civil Code (Código Civil, Gaceta de Madrid, No. 206, 25/07/1889) or by the or by the laws of the different regions of Spain. In any case, in order to determine both the modality of shared custody to be adopted and the temporality of the exchanges, the autonomy of the will of the parties will prevail, so that the judicial authority will only intervene in the absence of an agreement. To this end, it should be understood that the specific configuration of the custody regime should be included in the regulatory agreement submitted by the parents. ${ }^{1}$ Not in vain, in the event that the parties limit themselves to agreeing on the shared custody regime without foreseeing its specific content, it seems that it would be appropriate for the judge to make use of the power granted to him by article 777.4 of the Law of Civil Procedure (BOE (Official State Gazette), No. 7, 08/01/2000) and require the parents to complete this point.

I will now address separately the two issues that arise in determining the specific configuration of the shared custody regime. To this end, I shall begin by referring to the forms of physical organization that it may present (warning that, although this is an issue that is closely related to the attribution made of the use of the family home, I am not going to dwell on the criteria for the attribution of that home). Subsequently, I will refer to the temporal distribution.

\section{Physical organization}

The legal scholarship and commentary has generally identified two possible alternatives for the organization of the system of shared custody: ${ }^{2}$ that the children remain

1 This requirement was expressly provided for in the Law of the Basque Country 7/2015 of 30 June on family relations in cases of separation or break-up of parents (BOE (Official State Gazette) No. 176, 24/07/2015), Articles 5.2 a).3 and 9.1, and was also intended to be introduced in the Civil Code by the failed Draft law on the exercise of parental authority and other measures to be adopted after the break-up of cohabitation in 2013 (Document CE-D-2014-438, File number: 438/2014) (Art. 1.1).

2 See: Tamayo, S., La custodia compartida como alternativa legal, "Revista Crítica de Derecho Inmobiliario" 2007, No. 700, p. 705; Moreno, V. and Gaudet, J., La problemática del uso de la vivienda familiar en los supuestos de custodia compartida: reflexión comparativa España y EEUU, "La Ley" 
in the same home and the parents rotate (known as "nest custody") or that the children rotate between the homes of their parents (known as "suitcase child").

However, according to some authors, ${ }^{3}$ I believe that we should talk about a third organizational alternative: one in which both parents stay in the same house with their minor children. ${ }^{4}$ Although it is the least common option in practice (since it is normal for the spouses to cease living together after the break-up), it is perfectly admissible. In any case, this assumption raises no doubt from the point of view of their physical organization, so I will not dwell more on it.

Returning to the two most frequent organizational alternatives, the first one I have mentioned is what our legal writings have called "nest custody", 5 "house nest" ${ }^{\circ}$ or "child nest". This means that the children remain constantly in the family home and it is the parents who rotate. ${ }^{7}$

Although a priori it may seem to be the solution that least affects the stability of the children ${ }^{8}$ and is the fairest for the parents (since both will be able to enjoy the use of the family home on equal terms), the fact is that in practice it has several disadvantages.

First of all, I believe that this form of organization of shared custody can be a source of constant conflict between parents, ${ }^{9}$ which can end up harming the

2009, No. 7179, pp. 1763-1764; and Berrocal, A.I., Los criterios para la atribución del régimen de guarda y custodia compartida, "La Ley Derecho de Familia" 2014, No. 3, p. 48.

3 See: Pérez, A.A., El interés del menor y la custodia compartida (Comentario de la sentencia de la Audiencia Provincial de Asturias, sección $7^{a}$, de 7 de noviembre de 2003. Publicada en la Revista de Derecho Familiar, núm. 24 de julio de 2004. Págs. 221 y 222), "Revista de Derecho de Familia" 2005, No. 26, p. 277; and Messía, J.A., El tratamiento de la custodia compartida en el Anteproyecto de Ley sobre el ejercicio de la corresponsabilidad parental, "La Ley Derecho de Familia" 2014, No. 3, pp. 2-20, p. 12.

4 This is the only case in which it is possible to speak of shared custody in the strict sense, since in the cases we are going to see below, both parents alternate in the care of the children, but clearly do not share custody. However, I will continue to use the term shared custody to refer to all the assumptions.

5 See: González, J.P., El derecho de uso de la vivienda familiar en los supuestos de guarda y custodia compartida, "La Ley" 2009, No. 7206, p. 2052; Goñi, M., La vivienda familiar en caso de custodia compartida. Sus implicaciones en el Derecho de las cosas, "Revista Crítica de Derecho Inmobiliario" 2013, No. 736, p. 1144; and Ureña, B., Vivienda familiar y custodia compartida (a propósito de la STS núm. 594/2014, de 24 de octubre), "La Ley Derecho de Familia" 2015, No. 6, p. 10.

6 See: Berrocal, A.I., op. cit., p. 48.

7 See: Pérez, A.A., El interés del menor y la custodia compartida..., p. 277.

8 See: Moreno, V. and Gaudet, J., op. cit., p. 1764.

9 This has also been understood by our jurisprudence (see: Judgment of the Provincial Court of Barcelona of 21 February 2008, JUR 2008\144903 and Judgment of the High Court of Justice of Catalonia of 5 September 2008, RJ 2009\1449) and by our scholars and commentators (see: Zarraluqui, 
interests of the child. Sharing a home (even if it is alternately) always causes problems, as it involves sharing various items and objects (bedrooms, wardrobes, clothes, etc. $)^{10}$ and having to distribute cleaning tasks. Disputes may also arise over the payment of the various expenses generated by the home or the acquisition of products necessary for the house (cleaning, food, etc.). In addition, the situation will be aggravated in the event that one of the two parents rebuilds his or her life with a new partner. ${ }^{11}$

On the other hand, for this possibility to be viable, it is necessary for parents to have some purchasing power. Normally they will have to have three homes ${ }^{12}$ (in addition to the one in which the child will constantly reside, each parent will have to have their own home, where they will live during the periods when they are not with the child). Although it is also possible to establish this option when they only have two homes (the family home, and another that is occupied by each parent during the periods in which they do not have to care for their children), ${ }^{13}$ this would involve sharing not one, but two homes, which would multiply the problems I referred to in the immediately preceding paragraph. ${ }^{14}$

Notwithstanding the foregoing, the aforementioned drawbacks have not impeded that in some cases our courts have opted for this alternative. ${ }^{15}$ And it is

L., La guarda y custodia compartida: pautas para su correcta aplicación, "Economist \&, Jurist" 2006, No. 104, p. 64; and Hernando, S., La intervención del Ministerio Fiscal en los procesos de guarda y custodia. Especial referencia a la guarda y custodia compartida, "Estudios Jurídicos" 2010, No. 2010, p. 13).

10 See: Domingo, J., Custodia y nido compartido: todo cambia, "Actualidad Jurídica Aranzadi" 2014, No. 891, p. 5.

11 See: Esparza, C., La guarda compartida en el Código Civil español y en la Ley autonómica valenciana, "Revista Boliviana de Derecho" 2014, No. 174, p. 194.

12 See: Giralt, N., Las modalidades de guarda y custodia en el ordenamiento jurídico español, in: Herrera, R. et al. (eds.), Derecho y familia en el siglo XXI, Almería 2011, p. 808; De la Iglesia, M.I., Custodia compartida y el derecho de uso de la vivienda familiar: análisis jurisprudencial, "Revista Crítica de Derecho Inmobiliario" 2012, No. 732, p. 2317; and De Verda, J.R. and Carapezza, G., El derecho de uso de la vivienda familiar en las crisis familiares: comparación entre las experiencias jurídicas española e italiana, "Revista Crítica de Derecho Inmobiliario" 2015, No. 752, p. 3391.

13 See: González, J.P., op. cit., p. 2053; and De la Iglesia, M.I., op. cit., p. 2317.

14 However, we did find some judicial pronouncement in which this form of custody has been chosen despite the fact that the family had only two dwellings (see: Judgment of 3 October 2008 of the Court of First Instance No. 8 of Gijón, AC 2008\1963).

15 See: Judgment of the Provincial Court of Castellón of 4 October 2005, JUR 2005\274311; Judgment of the Provincial Court of Castellón of 23 October 2006, JUR 2007\228244; Judgment of the Provincial Court of Huelva of 20 March 2007, JUR 2007\272774; Judgment of the Provincial Court of Castellón of 28 May 2008, JUR 2008\274860; Judgment of the Provincial Court of Madrid of 27 July 2007, JUR 2007\346934; Judgment of the Provincial Court of Madrid of 28 October 2009, 
that, which there will be cases in which the concurrent circumstances demand to adopt this formula (for example, when the minor suffers some type of pathology that requires his rest in the same domicile). ${ }^{16}$

The other option for organizing joint custody is for children to rotate between their parents' homes, a modality commonly known as "suitcase child". ${ }^{17}$ In my opinion, this is the most recommendable alternative in most of the cases (this has also been understood by a good part of our jurisprudence). ${ }^{18}$

However, it is true that this form of organization also has a major drawback, and that is that it can affect the stability of children, ${ }^{19}$ who will be forced to make continuous changes (precisely the situation which has compelled this form of organization to be called 'child suitcase'). However, this disadvantage can be minimised if

JUR 2010\38880; Judgment of the Provincial Court of Madrid of 3 March 2010, JUR 2010\166006; Judgment of the Provincial Court of Zaragoza of 29 November 2011, JUR 2011\431895; Judgment of the Provincial Court of Zaragoza of 6 September 2012, JUR 2012\318794; Judgment of the Provincial Court of Barcelona of 11 March 2013, JUR 2013\169985; Judgment of the Provincial Court of Madrid of 28 June 2013, JUR 2013\263874; Judgment of the Alicante Provincial Court of 24 October 2013, JUR 2014 17596; Judgment of the Provincial Court of Teruel of 5 March 2014, JUR 2014\118875; Judgment of the Provincial Court of Zaragoza of 8 July 2014, JUR 2014\199874; Judgment of the Provincial Court of Cordoba of 30 July 2014, JUR 2014\258259; Judgment of the Provincial Court of Guipúzcoa of 26 September 2014, JUR 2014\298695; Judgment of the Provincial Court of Cantabria of 28 May 2015, JUR 2015\265595 and Judgment of the Provincial Court of Zaragoza of 30 June 2015, JUR 2015\181856.

16 See: Meco, F., La alternancia y cercanía de domicilios de los progenitores como criterio de atribución de la custodia compartida. Comentario a la STS núm. 495/2013, de 19 de julio (EDJ 2013, 149996), "Revista Boliviana de Derecho" 2015, No. 19, p. 593.

17 See: Pérez, C., ¿Excepcionalidad de la salomónica medida sobre custodia compartida en el Código Civil? Algunas referencias, JURisprudenciales y legales, "Aranzadi Civil-Mercantil" 2011, No. 8, p. 26; and Escribano, P., Guarda y custodia compartida y atribución de la vivienda familiar, "Práctica de Tribunales" 2016, No. 119, p. 11.

18 See: Judgment of the Alicante Provincial Court of 7 July 1997, AC 1997\1591; Judgment of the Provincial Court of Madrid of 20 April 1999, AC 1999\956; Judgment of the Provincial Court of Girona of 25 February 2001, AC 2001\1827; Judgment of the Provincial Court of Las Palmas of 10 November 2004, JUR 2005\22343; Judgment of the Provincial Court of Jaén of 9 May 2005, JUR 2005\159766; Judgment of the Provincial Court of Cordoba of 24 April 2006, JUR 2006\230967; Judgment of the Provincial Court of Girona of 3 November 2006, JUR 2007\105329; Judgment of the Provincial Court of Barcelona of 20 February 2007, JUR 2007\101427; Judgment of the Provincial Court of Barcelona of 5 October 2007, JUR 2008\13568; Judgment of the Provincial Court of Barcelona of 21 February 2008, JUR 2008\144903; Judgment of the Provincial Court of Barcelona of 8 October 2008, JUR 2009\38058; Judgment of the Provincial Court of Toledo of 16 May 2008, JUR 2008\330924; Judgment of the Alicante Provincial Court of 24 April 2009, AC 2009\1040; Judgment of the Provincial Court of Barcelona of 14 December 2011, JUR 2012 21752 and Judgment of the Provincial Court of Barcelona of 9 April 2014, AC 2014\689.

19 See: Coll, M.J., La custodia compartida, "Aequalitas: Revista Jurídica de Igualdad de Oportunidades Entre Mujeres y Hombres” 2014, No. 7, p. 34. 
the parents' homes are close to each other and if the periods of permanence with each parent are sufficiently long (to avoid the continuous transfer of the child).

In conclusion, if we consider the disadvantages of one or the other system of organization, in my opinion it is more advisable for parents to remain in their respective homes and for their children to rotate (but trying to take all the necessary precautions so that this measure affects the stability of minors as little as possible). This does not prevent the reality, however, that there are certain cases in which it is advisable for the minor to remain in the same home and for the parents to rotate.

\section{Allocation of time between parents}

In the event that the parties do not agree and it has to be the judge who decides about the temporary distribution of the cohabitation, he will do so based on the different circumstances that concur in the specific case. ${ }^{20}$

We only find timid references to the aspect of temporal distribution in the Code of Regional Law of Aragon (BOA (Official Gazette of Aragon) No. 67, 29/03/2011) and in the Valencian Law 5/2011 of 1 April on family relations for children whose parents do not live together (BOE (Official State Gazette), No. 98, 25/04/2011), which are contradictory to each other. While the first points out that shared custody does not entail an arithmetical distribution of the time spent with one and the other parent (see Exposition of Reasons for the Code of Regional Law of Aragon); the second seems to establish just the opposite, pointing out in article 3 a) that shared custody is characterized "(...) by an equal and rational distribution of the time of cohabitation of each of the parents with their minor sons and daughters (...)”.

In our jurisprudence ${ }^{21}$ and legal commentary and scholarship ${ }^{22}$ there is almost unanimity in considering that, in general, shared custody does not necessarily imply

20 See: Tena, I., La ruptura de pareja con hijos: la opción por la custodia compartida, in: Factores y contenidos de la evolución del Derecho de Familia, Montevideo 2008, p. 64; and Pérez, L., La jornada laboral del padre no puede ser un obstáculo para la custodia compartida, "Revista de Derecho de Familia" 2014, No. 64, p. 308.

21 See: Judgment of the Supreme Court of 11 March 2010, RJ 2010\2340: “(...) Shared custody is not synonymous with sharing $50 \%$ of coexistence between both parents (...)". See also: Judgment of the High Court of Justice of Catalonia of 31 July 2008, RJ 2009|643; Judgment of the Provincial Court of Pontevedra of 8 May 2003, JUR 2003\228964 and Judgment of the Provincial Court of Girona of 10 June 2011, JUR 2011\290768.

22 See: Martínez de Aguirre, C., La regulación de la custodia compartida en la Ley de igualdad de las relaciones familiares ante la ruptura de la convivencia de los padres", in: Actas de los vigésimos encuentros del Foro de Derecho Aragonés, Zaragoza 2010, p. 162; Serrano, J.A., Guarda y custodia de los hijos y régimen de visitas en Aragón, in: Bayod, M.C. et al. (eds.), Relaciones entre padres e hijos en Aragón: ¿un modelo a exportar?, Zaragoza 2013, p. 40; Monterroso, E. and Goñi, M., 
an equal distribution of time. ${ }^{23}$ In this sense, the failed Draft law on the exercise of parental co-responsibility and other measures to be adopted after the rupture of cohabitation presented by the government on 19 July 2013 was also pronounced, whose Exposition of Reasons expressly stated that shared custody does not necessarily imply that the periods of alternation are equal ${ }^{24}$.

Therefore, with the sole exception of the Valencian Law 5/2011 of 1 April 2011 on family relations for children whose parents do not live together (BOE (Official State Gazette), No. 98, 25/04/2011) (in which, as I said, it did seem to require an equal distribution of time), it is not necessary to speak of shared custody that the child is in the company of each parent exactly fifty percent of the time.

However, the fact that joint custody does not require an equal sharing of time may pose problems in distinguishing it from an exclusive custody regime that involves a comprehensive regime of communication, relationship and stay for the non-custodial parent. For this reason, it seems reasonable to understand that in order for there to be a proper shared custody regime, children should remain a minimum of time with each of their parents ${ }^{25}$ (since this is the key data that will allow us to distinguish it from exclusive custody with a broad regime of communication and stays). ${ }^{26}$ In this respect, legal scholars and commentators have considered that it is possible to speak of shared custody when the children are in the company of each parent at least between forty and forty-five percent of the time. ${ }^{27}$

Análisis de la regulación legal de la custodia compartida tras la separación y el divorcio: una propuesta de lege ferenda, CEFLegal: "Revista Práctica del Derecho" 2011, No. 131, p. 54; Pinto, C., La custodia compartida en la práctica judicial española: los criterios y factores para su atribución, "Misión Jurídica: Revista de Derecho y Ciencias Sociales" 2015, No. 9, 2015, p. 149; and Messía, J.A., El reparto de los tiempos de estancia de los hijos menores con los progenitores en los casos de custodia compartida, "La Ley Derecho de Familia" 2016, No. 11, p. 2.

23 However, we also find some authors who consider that shared custody in any case requires an equal distribution of time (see: Romero, F., Coparentalidad y género, "Intervención Psicoeducativa en la Desadaptación Social" 2009, No. 2, p. 20).

24 See: Statement of reasons for the Draft Law on the exercise of parental co-responsibility and other measures to be adopted after the break-up of cohabitation: “(...) without shared custody necessarily implying an alternation of the residence of the children with their parents in equal periods, but in an adequate time for the fulfilment of the purpose of custody (...)".

25 At this point I disagree with those who claim that it is possible to speak of shared custody even in cases where the child permanently resides with one of the parents (see: Lathrop, F., Custodia compartida de los hijos, Madrid, 2008, p. 511).

26 However, other criteria may also be taken into account, such as whether or not there are overnight stays with both parents (see: Martínez de Aguirre, C., op. cit., pp. 147-148).

27 See: López, A., El tratamiento en derecho español de la custodia de los hijos menores en las crisis de pareja: la novedosa opción del legislador aragonés por la custodia compartida, "Revista Boliviana de Derecho" 2015, No. 19, p. 216. 
In any case, if we look at the casuistry, the truth is that it is usually established as an equal distribution of the time of coexistence with one parent and another.

As for the specific duration of the periods that the minor will remain with both parents, there are multiple options, finding assumptions in which it has been distributed by hours, ${ }^{28}$ by days, ${ }^{29}$ by weeks, ${ }^{30}$ by fortnights ${ }^{31}$ (in reality, these will be

28 See: Judgment of the Provincial Court of Castellón of 14 October 2003, JUR $2003 \backslash 264777$.

29 See: Judgment of the Provincial Court of Jaén of 9 May 2005, JUR 2005\159766; Judgment of the Provincial Court of Girona of 3 November 2006, JUR 2007\105329; Judgment of the Provincial Court of the Balearic Islands of 29 December 2006, JUR 2007\89096; Judgment of the Provincial Court of Barcelona of 20 February 2007, JUR 2007\101427; Judgment of the Provincial Court of Zaragoza of 3 May 2011, JUR 2011\269689; Judgment of the Provincial Court of Barcelona of 9 April 2014, AC 20141689; Judgment of the Provincial Court of Barcelona of 12 January 2016, JUR 2016\102213; Judgment of the Provincial Court of Cadiz of 3 May 2017, JUR 2017\183872; Judgment of the Provincial Court of Barcelona of 16 March 2017, JUR 2017\183605; Judgment of the Murcia Provincial Court of 11 January 2018, JUR $2018 \backslash 61929$ and Judgment of the Provincial Court of Barcelona of 16 January, 2018 JUR $2018 \backslash 38141$.

30 See: Judgment of the Supreme Court of 17 November 2015, RJ 2015\5392; Judgment of the Supreme Court of 17 February 2017, RJ 2017\483; Judgment of the Supreme Court of 17 January 2018, RJ 2018\100; Judgment of the Supreme Court of 29 January 2018, RJ 2018\199 and Judgment of the Supreme Court of 4 April 2018, JUR 2018\98270. See also: Judgment of the Court of Alicante Province of 8 May 2006, JUR 2006\248961; Judgment of the Court of the Province of Las Palmas of 14 June 2006, JUR 2006\211237; Judgment of the High Court of the Province of Santa Cruz de Tenerife of 27 September 2006, JUR 2007\2044; Judgment of the High Court of the Province of the Balearic Islands of 28 November 2006, JUR 2007\240039; Judgment of the Court of Alicante Province of 1 February 2007, JUR 2007\265890; Judgment of the Provincial Court of Barcelona of 1 October 2007, JUR 2008\14175; Judgment of the Provincial Court of Barcelona of 3 March 2010, JUR 2010\177860; Judgment of the Provincial Court of Valencia of 21 February 2011, JUR 2011\76122; Judgment of the Provincial Court of Barcelona of 14 December 2011, JUR 2012 \21752; Judgment of the Alicante Provincial Court of 16 January 2012, JUR 2012\216263; Judgment of the Provincial Court of Zaragoza of 7 February 2012, JUR 2012163159; Judgment of the Provincial Court of Barcelona of 10 April 2012, JUR 2012\195763; Judgment of the Provincial Court of Ourense of 1 June 2012, JUR 2012\228284; Judgment of the Alicante Provincial Court of 12 July 2013, JUR 2013\350085; Judgment of the Provincial Court of Valencia of 17 July 2014, JUR 2014\252664; Judgment of the Provincial Court of Castellón of 2 September 2014, JUR 2015\53194; Judgment of the Alicante Provincial Court of 25 October 2013, JUR 2014\5732; Judgment of the Alicante Provincial Court of 30 October 2013, JUR 2014 17998 ; Judgment of the Provincial Court of Navarre of 20 January 2017, JUR 2017\137776; Judgment of the Provincial Court of Zaragoza of 14 March 2017 JUR, 2017\107757; Judgment of the Provincial Court of Valladolid of 12 January 2018, JUR 2018\52352; Judgment of the Provincial Court of Madrid of 16 January 2018, JUR 2018 74934 ; Judgment of the Provincial Court of Valladolid of 22 January 2018, JUR 2018\65110; Judgment of the Provincial Court of Cordoba of 23 January 2018, JUR 2018\46596; Judgment of the Provincial Court of Valladolid of 24 January 2018, JUR 2018|64183; Judgment of the Provincial Court of Asturias of 25 January 2018, JUR 2018\64401; Judgment of the Provincial Court of Madrid of 5 February 2018, JUR 2018\91094 and Judgment of the Provincial Court of Barcelona of 6 February 2018, JUR 2018\82473.

31 See: Judgment of the Supreme Court of 19 July 2013, RJ 2013\5002. See also: Judgment of the Provincial Court of Barcelona of 27 July 2006, JUR 2007\124388; Judgment of the Provincial Court 
periods of fourteen days, since to apply literally the distribution by fortnights would suppose that the changes would take place each time a different day of the week), ${ }^{32}$ by months,,${ }^{33}$ by bimesters, ${ }^{34}$ by trimesters,${ }^{35}$ by quartermesters, ${ }^{36}$ by periods of five

of the Balearic Islands of 27 February 2007, JUR 2008\133674; Judgment of the Provincial Court of Valencia of 31 May 2007, JUR 2007\259947; Judgment of the Provincial Court of Barcelona of 5 October 2007, JUR 2008\13568; Judgment of the Provincial Court of Madrid of 17 October 2007, AC 2007\2330; Judgment of the Provincial Court of Valencia of 9 April 2008, JUR 2008\189008; Judgment of the Provincial Court of Toledo of 16 May 2008, JUR 2008\330924; Judgment of the Provincial Court of Barcelona of 27 January 2010, JUR 2010\148898; Judgment of the Provincial Court of Valencia of 21 February 2011, JUR 2011 76122 ; Judgment of the Provincial Court of the Balearic Islands of 20 September 2011, JUR 2011\347585; Judgment of the Provincial Court of Zaragoza of 28 February 2012, JUR 2012 188042; Judgment of the Provincial Court of Valencia of 21 October 2013, JUR 2013\351021; Judgment of the Provincial Court of Valencia of 14 November 2013, JUR 2014\10308; Judgment of the Provincial Court of Valencia of 5 May 2014, JUR 2014\200932; Judgment of the Alicante Provincial Court of 5 May 2015, JUR 2015\167918; Judgment of the Provincial Court of Palencia of 28 July 2017, JUR 2017\234466 and Judgment of the Provincial Court of Cadiz of 11 January 2018, JUR 2018\82165.

32 See: Ferrer, M., Algunas ideas procesales y sustantivas de las Sentencias de Primera Instancia de Zaragoza, en los dos primeros años de preferencia en la custodia compartida, in: Actas de los vigésimosegundos encuentros del Foro de Derecho Aragonés, Zaragoza 2012, p. 361.

33 See: Judgment of the Provincial Court of Valencia of 1 March 2006, JUR 2006/243590; Judgment of the Provincial Court of Asturias of 29 November 2006, JUR 2007\23523; Judgment of the Provincial Court of Valencia of 15 January 2007, JUR 2007\235242; Judgment of the Provincial Court of Valencia of 19 June 2007, JUR 2007\258457; Judgment of the Provincial Court of Seville of 14 October 2010, JUR 2011\82839; Judgment of the Provincial Court of Tarragona of 26 November 2010, JUR 2011\79232; Judgment of the Provincial Court of Zaragoza of 6 September 2011, JUR 2011\329999; Judgment of the Provincial Court of Zaragoza of 14 February 2012, JUR 2012 \73103; Judgment of the Alicante Provincial Court of 5 December 2012, JUR 2013\116336; Judgment of the Provincial Court of Valencia of 14 October 2013, JUR 2013\351228; Judgment of the Provincial Court of Valencia of 19 May 2014, JUR 2014\174658 and Judgment of the Provincial Court of Valencia of 18 June 2014, JUR 2014\201095.

34 See: Judgment of the Provincial Court of Zaragoza of 17 January 2012, JUR 2012|35561; Judgment of the Provincial Court of Zaragoza of 22 May 2012, JUR 2012\184960; Judgment of the Provincial Court of Burgos of 15 May 2012, JUR 2012\234462 and Judgment of the Provincial Court of Cadiz of 10 January 2018, JUR 2018\82579.

35 See: Judgment of the Supreme Court of 11 March 2010, RJ 2010\2340. See also: Judgment of the Provincial Court of Madrid of 22 September 2006, JUR 2007\31052; Judgment of the Provincial Court of Madrid of 12 December 2007, JUR 2008\82720; Judgment of the Provincial Court of Madrid of 22 December 2008, JUR 2009 88147 ; Judgment of the Provincial Court of Madrid of 28 October 2009, JUR 2010\38880; Judgment of the Provincial Court of Zaragoza of 21 June 2011, JUR 2011\265026 and Judgment of the Provincial Court of Zaragoza of 6 September 2012, JUR $2012 \backslash 318794$.

36 See: Judgment of the Supreme Court of 12 May 2017, RJ 2017\2203. 
months, ${ }^{37}$ by semesters, ${ }^{38}$ by years, by school courses, ${ }^{39}$ etc. There are those who have even raised the possibility that the periods of alternation of minors are not fixed either in the regulatory agreement or in the sentence, leaving the parties to decide at each moment on the temporary distribution they deem appropriate. ${ }^{40}$ However, in my opinion, this can lead to a certain degree of legal uncertainty and end up becoming an important source of conflict.

With regard to the most appropriate temporal distribution, in my opinion, long periods of alternation (from 15 days) are generally preferable, as this minimises the risk that continuous transfers end up affecting the stability of the child. This has also been understood by a good part of our jurisprudence ${ }^{41}$ and legal scholars. ${ }^{42}$ Obviously, if long periods of alternation are established, it may be advisable to establish a regime of visits in favour of the parent who is not with the minors at all times.

37 See: Judgment of the Provincial Court of Barcelona of 1 July 2009, JUR $2009 \backslash 418335$.

38 See: Judgment of the Provincial Court of Córdoba of 1 March 2004, JUR 2004\125769; Judgment of the Provincial Court of Las Palmas of 15 April 2004, JUR 2004\152448; Judgment of the Provincial Court of the Balearic Islands of 17 September 2004, JUR 2004\287192; Judgment of the Provincial Court of Santa Cruz de Tenerife of 25 July 2005, JUR 2005\222818; Judgment of the Provincial Court of Valencia of 1 March 2007, JUR 2007\274051; Judgment of the Provincial Court of Cantabria of 3 April 2007, JUR 2007\263125; Judgment of the Provincial Court of Zaragoza of 21 June 2011, JUR 2011\265026; Judgment of the Provincial Court of Zaragoza of 29 November 2011, JUR 2011\431895 and Judgment of the Provincial Court of Zaragoza of 9 May 2012, JUR 2012\199240.

39 See: Judgment of the Provincial Court of Córdoba of 10 March 2005, JUR 2005\144585; Judgment of the Provincial Court of Cordoba of 24 April 2006, JUR 2006\230967; Judgment of the Provincial Court of Madrid of 29 September 2006, JUR 2006\268395; Judgment of the Provincial Court of Barcelona of 20 December 2006, JUR 2007\143259; Judgment of the Provincial Court of Madrid of 25 May 2007, JUR 2007\312903 and Judgment of the Provincial Court of Zaragoza of 24 January 2012, JUR 2012\43195.

40 See: Pérez, A., La guarda y custodia compartida de los hijos sometidos a patria potestad, "Anuario de la Facultade de Dereito da Universidade da Coruña" 2005, No. 9, p. 688.

41 See: Judgment of the Provincial Court of Barcelona of 20 December 2006, JUR 2007\143259; Judgment of the Provincial Court of Madrid of 21 November 2011, JUR 2011\432435; Judgment of the Provincial Court of Zaragoza of 25 April 2012, JUR 2012\162327 and Judgment of the High Court of Justice of Aragon of 15 November 2013, RJ 2013\8501.

42 See: Bellod, E., Hijos menores, custodia compartida e individual, vivienda familiar y gastos de los hijos, in: Bayod, M.C. et al. (eds.), Relaciones entre padres e hijos en Aragón: ¿un modelo a exportar?, Zaragoza 2013, p. 323. 
However, in the case of very young children, shorter and more frequent periods of alternation ${ }^{43}$ (by the week or even by the day) are more advisable, and these can be extended as the children grow older. ${ }^{44}$

\section{References}

Bellod, E., Hijos menores, custodia compartida e individual, vivienda familiar y gastos de los hijos, in: Bayod, M.C. et al. (eds.), Relaciones entre padres e hijos en Aragón: ¿un modelo a exportar?, Zaragoza 2013.

Berrocal, A.I., Los criterios para la atribución del régimen de guarda y custodia compartida, "La Ley Derecho de Familia" 2014, No. 3.

Clemente, M., Aspectos psicológicos y jurídicos de la guarda y custodia de los hijos, Madrid 2014.

Coll, M.J., La custodia compartida, "Aequalitas: Revista Jurídica de Igualdad de Oportunidades Entre Mujeres y Hombres" 2014, No. 7.

De la Iglesia, M.I., Custodia compartida y el derecho de uso de la vivienda familiar: análisis jurisprudencial, "Revista Crítica de Derecho Inmobiliario" 2012, No. 732.

De Verda, J.R. and Carapezza, G., El derecho de uso de la vivienda familiar en las crisis familiares: comparación entre las experiencias jurídicas española e italiana, "Revista Crítica de Derecho Inmobiliario" 2015, No. 752.

Domingo, J., Custodia y nido compartido: todo cambia, "Actualidad Jurídica Aranzadi" 2014, No. 891.

Escribano, P., Guarda y custodia compartida y atribución de la vivienda familiar, "Práctica de Tribunales" 2016, No. 119.

Esparza, C., La guarda compartida en el Código Civil español y en la Ley autonómica valenciana, "Revista Boliviana de Derecho" 2014, No. 174.

43 This thesis is supported by the child psychology studies carried out by the Children's Rights Council (goo.gl/rVQKk5, accessed 31.07.2020). This also emerges from the Report of 25 September 2002 (goo.gl/wxaCDt, accessed 6.04.2018), drawn up by the "Asociación de Padres de Familia Separados" (APFS) and the "Federación Andaluza de Padres y Madres Separados" (FASE), with the support of the "Asociación Gallega de Padres y Madres Separados", the "Federación de Euskadi de Padres y Madres Separados" (KIDETZA), the "Unión de Separados y Separadas de Madrid" and the "Asociación Azulfuerte" (see page 12). See also: Clemente, M., Aspectos psicológicos y jurídicos de la guarda y custodia de los hijos, Madrid 2014, p. 118.

44 By way of example, this is the solution adopted by the Judgment of the Provincial Court of Castellón of 23 October 2006, in which it is decided on the custody of a child under the age of two. The Provincial Court establishes a shared custody with weekly alternation until the minor reaches six years of age, after which the alternation will be for periods of five months. Although the solution arrived at by the court seems to me to be adequate, I believe that it would have been convenient for the change to take place in a more progressive manner. 
Ferrer, M., Algunas ideas procesales y sustantivas de las Sentencias de Primera Instancia de Zaragoza, en los dos primeros años de preferencia en la custodia compartida, in: Actas de los vigésimosegundos encuentros del Foro de Derecho Aragonés, Zaragoza 2012.

Giralt, N., Las modalidades de guarda y custodia en el ordenamiento jurídico español, in: Herrera, R. et al. (eds.), Derecho y familia en el siglo XXI, Almería 2011.

González, J.P., El derecho de uso de la vivienda familiar en los supuestos de guarda y custodia compartida, "La Ley" 2009, No. 7206.

Goñi, M., La vivienda familiar en caso de custodia compartida. Sus implicaciones en el Derecho de las cosas, "Revista Crítica de Derecho Inmobiliario" 2013, No. 736.

Hernando, S., La intervención del Ministerio Fiscal en los procesos de guarda y custodia. Especial referencia a la guarda y custodia compartida, "Estudios Jurídicos" 2010, No. 2010.

Lathrop, F., Custodia compartida de los hijos, Madrid, 2008.

López, A., El tratamiento en derecho español de la custodia de los hijos menores en las crisis de pareja: la novedosa opción del legislador aragonés por la custodia compartida, "Revista Boliviana de Derecho" 2015, No. 19.

Martínez de Aguirre, C., La regulación de la custodia compartida en la Ley de igualdad de las relaciones familiares ante la ruptura de la convivencia de los padres, in: Actas de los vigésimos encuentros del Foro de Derecho Aragonés, Zaragoza 2010.

Meco, F., La alternancia y cercanía de domicilios de los progenitores como criterio de atribución de la custodia compartida. Comentario a la STS núm. 495/2013, de 19 de julio (EDJ 2013, 149996), "Revista Boliviana de Derecho" 2015, No. 19.

Messía, J.A., El tratamiento de la custodia compartida en el Anteproyecto de Ley sobre el ejercicio de la corresponsabilidad parental, "La Ley Derecho de Familia" 2014, No. 3.

Messía, J.A., El reparto de los tiempos de estancia de los hijos menores con los progenitores en los casos de custodia compartida, "La Ley Derecho de Familia" 2016, No. 11.

Monterroso, E. and Goñi, M., Análisis de la regulación legal de la custodia compartida tras la separación y el divorcio: una propuesta de lege ferenda, CEFLegal: "Revista Práctica del Derecho" 2011, No. 131.

Moreno, V. and Gaudet, J., La problemática del uso de la vivienda familiar en los supuestos de custodia compartida: reflexión comparativa España y EEUU, "La Ley" 2009, No. 7179.

Pérez, C., ¿Excepcionalidad de la salomónica medida sobre custodia compartida en el Código Civil? Algunas referencias jurisprudenciales y legales, "Aranzadi civil-mercantil" 2011, No. 8.

Pérez, L., La jornada laboral del padre no puede ser un obstáculo para la custodia compartida, "Revista de Derecho de Familia" 2014, No. 64.

Pérez, A.A., El interés del menor y la custodia compartida (Comentario de la sentencia de la Audiencia Provincial de Asturias, sección 7a de 7 de noviembre de 2003. Publicada en la Revista de Derecho Familiar, núm. 24 de julio de 2004. Págs. 221 y 222), "Revista de Derecho de Familia" 2005, No. 26. 
Pérez, A., La guarda y custodia compartida de los hijos sometidos a patria potestad, "Anuario de la Facultade de Dereito da Universidade da Coruña” 2005, No. 9.

Pinto, C., La custodia compartida en la práctica judicial española: los criterios y factores para su atribución, "Misión Jurídica: Revista de Derecho y Ciencias Sociales" 2015, No. 9, 2015.

Romero, F., Coparentalidad y género, "Intervención Psicoeducativa en la Desadaptación Social" 2009, No. 2.

Serrano, J.A., Guarda y custodia de los hijos y régimen de visitas en Aragón, in: Bayod, M.C. et al. (eds.), Relaciones entre padres e hijos en Aragón: ¿un modelo a exportar?, Zaragoza 2013.

Tamayo, S., La custodia compartida como alternativa legal, "Revista Crítica de Derecho Inmobiliario" 2007, No. 700.

Tena, I., La ruptura de pareja con hijos: la opción por la custodia compartida, in: Factores y contenidos de la evolución del Derecho de Familia, Montevideo 2008.

Ureña, B., Vivienda familiar y custodia compartida (a propósito de la STS núm. 594/2014, de 24 de octubre), "La Ley Derecho de Familia" 2015, No. 6.

Zarraluqui, L., La guarda y custodia compartida: pautas para su correcta aplicación, “Economist \& Jurist" 2006, No. 104, pp. 60-66.

\section{CITATION}

Martínez Calvo, J., Shared custody configuration in Spanish law, "Acta Iuris Stetinensis” 2020, No. 4 (Vol. 32), 7-19, DOI: 10.18276/ais.2020.32-01. 